\title{
Hubungan antara merokok dengan terjadinya disfungsi ereksi pada sopir angkutan umum di Terminal Karombasan Manado
}

\author{
${ }^{1}$ Suryati Rusdi \\ ${ }^{2}$ Grace L. A. Turalaki \\ ${ }^{2}$ Lusiana Satiawati \\ ${ }^{1}$ Kandidat Skripsi Fakultas Kedokteran Universitas Sam Ratulangi Manado \\ ${ }^{2}$ Bagian Biologi Fakultas Kedokteran Universitas Sam Ratulangi Manado \\ Email: ulyrusdy@yahoo.com
}

\begin{abstract}
Smoking habit has become a culture in many countries in the world. During smoking, each cigarette can release morre than 4000 toxic chemicals such as nicotine, tar, carbon monoxide, and black tin. Smoking can cause health problem inter alia erectile dysfunction. This study was aimed to analyze the relationship between smoking and erectile dysfunction among public transportation drivers. This was an analytical survey study with a cross sectional design conducted at Terminal Karombasan Manado. There were 60 drivers as respondents. Data of respondent characteristic were obtained by interview and filling the IIEF questionnaires (International Index of Erectile Function) given directly to the respondents. The results showed that of 60 drivers, there were $86.7 \%$ that had erectile dysfunction. The Chisquare test analyzing the relationship between smoking and erectile dysfunction showed a $p$ value of 0.04. Conclusion: There was a significant relationship between smoking and erectile dysfunction among drivers of public transportation at Terminal Karombasan Manado.
\end{abstract}

Keywords: smoking, erectile dysfunction

\begin{abstract}
Abstrak: Kebiasaan merokok telah menjadi budaya di berbagai bangsa di belahan dunia. Setiap batang rokok yang dinyalakan mengeluarkan lebih dari 4000 bahan kimia beracun yang berbahaya, diantaranya nikotin, tar, karbon monoksida, dan timah hitam. Merokok dapat menyebabkan beberapa gangguan kesehatan salah satunya ialah disfungsi ereksi. Penelitian ini bertujuan untuk mengetahui adanya hubungan antara merokok dengan terjadinya disfungsi ereksi pada sopir angkutan umum. Jenis penelitian ialah survei analitik dengan desain potong lintang. Penelitian dilakukan di Terminal Karombasan Manado dengan jumlah responden 60 sopir angkutan umum. Data yang menyangkut karakteristik responden berdasarkan hasil penelitian, diperoleh dari wawancara dan menggunakan kuesioner IIEF (International Index of Erectile Function) yang dibagikan secara langsung pada responden. Hasil penelitian ini menunjukkan bahwa dari 60 sopir angkutan umum didapatkan $86,7 \%$ mengalami disfungsi ereksi. Uji Chi-square terhadap hubungan merokok dan disfungsi ereksi memndapatkan $p=0,04$. Simpulan: Terdapat hubungan bermakna antara merokok dan disfungsi ereksi pada sopir angkutan umum di Terminal Karombasan Manado.
\end{abstract}

Kata kunci: merokok, disfungsi ereksi

Disfungsi ereksi merupakan ketidakmampuan untuk mencapai atau mempertahankan kualitas ereksi penis yang optimal sehingga memungkinkan hubungan seksual yang memuaskan. ${ }^{1}$ Batasan tersebut menunjukkan bahwa proses fungsi seksual laki-laki mempunyai dua komponen yaitu mencapai keadaan ereksi dan mempertahankannya. $^{2}$

Pada tahun 2005 terdapat 322 juta pria mengalami disfungsi ereksi di seluruh dunia. Disfungsi ereksi ditemukan pada 52\% pria 
di Amerika, 32\% pria di Inggris, $26 \%$ pria di Jepang, dan $19 \%$ pria di Denmark. ${ }^{1}$ Pada tahun 1995 diperkirakan 152 juta pria mengalami disfungsi ereksi. ${ }^{3}$ Penelitian National Institutes of Health (NIH) tahun 2002 menunjukkan bahwa kurang lebih 15 juta sampai 30 juta laki-laki di Amerika mengalami disfungsi ereksi. Pada usia 40 tahun terdapat sekitar 5\% laki-laki mengalami keadaan disfungsi ereksi dan pada usia 65 tahun terdapat sekitar $15-25 \%$. Pada tahun 2025 jumlahnya diperkirakan akan menjadi 322 juta pria seiring dengan pertambahan jumlah manusia di dunia, artinya akan terjadi penambahan sebanyak 170 juta penderita dalam kurun waktu 30 tahun. Prevalensi disfungsi ereksi di Indonesia belum diketahui secara tepat, tetapi diperkirakan 16\% laki-laki usia 20-75 tahun di Indonesia mengalami disfungsi ereksi. $^{3}$

Rokok merupakan salah satu pembunuh paling berbahaya di dunia. Rokok ialah hasil olahan tembakau terbungkus yang meliputi kretek dan rokok putih yang dihasilkan dari tanaman Nicotiana tabacum, Nicotiana rustica, dan spesies lainnya atau sintetisnya yang mengandung nikotin dan tar dengan atau tanpa bahan tambahan. ${ }^{4}$ Laporan World Health Organization (WHO) tahun 2008 menyatakan bahwa lebih dari 1 milyar orang di dunia menggunakan tembakau dan menyebabkan kematian lebih dari 5 juta orang setiap tahunnya karena penyakit yang disebabkan oleh rokok. ${ }^{5,6}$

Sopir merupakan salah satu jenis pekerjaan yang setiap hari terpapar dengan jam kerja yang panjang sehingga menyebabkan kebanyakan sopir memilih merokok untuk menghabiskan waktu saat berada dalam kemacetan lalu lintas, menunggu antrian jalur penumpang, dan waktu senggang bersama sopir lainnya. Diluar jam kerja pun kemungkinan sopir tetap merokok dengan berbagai alasan. Kebiasaan merokok tersebut menambah risiko pekerjaan sopir terhadap terjadinya disfungsi ereksi.

Berdasarkan hal-hal di atas penulis tertarik ingin meneliti hubungan merokok dengan disfungsi ereksi pada sopir angkutan umum di Terminal Karombasan Manado.

\section{METODE PENELITIAN}

Jenis penelitian ini ialah survei analitik dengan desain potong lintang. Penelitian dilaksanakan di Terminal Angkutan Umum Karombasan Kota Manado pada bulan Oktober 2015 - Januari 2016. Populasi dalam penelitian ini ialah sopir angkutan umum Terminal Karombasan Kota Manado yang memenuhi kriteria inklusi dan eksklusi dengan jumlah responden 60 sopir.

Variabel dalam penelitian ini yaitu merokok sebagai variabel bebas dan disfungsi ereksi sebagai variabel terikat. Data yang menyangkut karakteristik responden berdasarkan hasil penelitian dengan menggunakan kuesioner yang dibagikan langsung pada responden.

Analisis univariat dilakukan untuk menjelaskan distribusi frekuensi dari masing-masing variabel yang diteliti yaitu merokok dan disfungsi ereksi. Pengaruh merokok terhadap disfungsi ereksi dianalisis dengan uji Chi-Square.

\section{HASIL PENELITIAN}

Distribusi frekuensi berdasarkan usia, tingkat pendidikan, dan masa kerja, kategori perokok, dan disfungsi ereksi dapat dilihat pada Tabel 1-5.

Tabel 1. Distribusi frekuensi responden berdasarkan usia

\begin{tabular}{ccc}
\hline Usia & $\mathbf{N}$ & $\mathbf{\%}$ \\
\hline$<20$ & 5 & 8,3 \\
$21-30$ & 17 & 28,3 \\
$31-40$ & 38 & 63,3 \\
Total & 60 & 100,0 \\
\hline
\end{tabular}

Tabel 2. Distribusi frekuensi responden berdasarkan tingkat pendidikan

\begin{tabular}{lcc}
\hline Pendidikan & N & \% \\
\hline SD & 8 & 13,3 \\
SMP & 20 & 33,3 \\
SMA & 31 & 51,7 \\
Sarjana & 1 & 1,7 \\
Total & 60 & 100,0 \\
\hline
\end{tabular}


Tabel 3. Distribusi frekuensi responden berdasarkan masa kerja

\begin{tabular}{ccc}
\hline Masa kerja & $\mathbf{N}$ & $\mathbf{\%}$ \\
\hline$<10$ & 36 & 60,0 \\
$11-20$ & 19 & 31,7 \\
$21-30$ & 5 & 8,3 \\
$31-40$ & 0 & 0 \\
Total & 60 & 100,0 \\
\hline
\end{tabular}

Tabel 4. Distribusi frekuensi kategori sopir perokok.

\begin{tabular}{ccc}
\hline Kategori & $\mathbf{N}$ & $\mathbf{\%}$ \\
\hline Ya & 52 & 86,7 \\
Tidak & 8 & 13,3 \\
Total & 60 & 100,0 \\
\hline
\end{tabular}

Tabel 5. Distribusi kategori disfungsi ereksi

\begin{tabular}{ccc}
\hline Kategori & $\mathbf{N}$ & $\mathbf{\%}$ \\
\hline Ya & 48 & 80,0 \\
Tidak & 12 & 20,0 \\
Total & 60 & 100,0 \\
\hline
\end{tabular}

Dari 52 responden yang mempunyai kebiasaan merokok $75,0 \%$ mengalami disfungsi ereksi sedangkan yang tidak mengalami disfungsi ereksi sebanyak $5,0 \%$. Data juga menunjukkan bahwa dari 8 responden yang tidak mempunyai kebiasaan merokok $11,7 \%$ mengalami disfungsi ereksi sedangkan yang tidak mengalami disfungsi ereksi sebanyak $8,3 \%$. Hasil uji Chi-square mendapatkan nilai $\mathrm{p}=$ $0,04(<0,05)$ yang menunjukkan terdapat hubungan merokok dengan disfungsi ereksi pada sopir angkutan umum. Nilai OR (Odds Ratio) $=10,714 \quad$ (95\%CI: (2,083$55,122)$ menunjukkan bahwa sopir dengan kebiasaan merokok mempunyai risiko mengalami disfungsi ereksi sebesar 10,7 kali lebih besar dibandingkan dengan sopir yang tidak mempunyai kebiasaan merokok.

\section{BAHASAN}

Disfungsi ereksi terjadi bila darah tidak mengalir bebas ke penis. Merokok dapat merusak pembuluh darah, nikotin menyempitkan pembuluh darah yang menuju penis sehingga mengurangi aliran darah dan tekanan darah menuju penis. Efek ini meningkat sejalan dengan waktu. Masalah ereksi ini merupakan peringatan awal bahwa tembakau telah merusak area lain dari tubuh. ${ }^{7}$

Dari penelitian 15 tahun terakhir, didapatkan bahwa merokok sangat berpengaruh dalam penurunan kualitas pembuluh darah dalam tubuh manusia. Seperti diketahui terdapat 2 faktor vaskuler penting yang menyebabkan terjadinya disfungsi ereksi, yakni tingkat aterosklerotik yang terjadi pada pembuluh darah dan adanya faktor risiko utama yang memengaruhi terjadinya penurunan kualitas pembuluh darah yaitu nikotin rokok Elhambly melaporkan bahwa mereka yang sudah berhenti merokok lebih kecil risikonya untuk menderita disfungsi ereksi dibandingkan dengan mereka yang masih merokok. ${ }^{8}$

\section{SIMPULAN}

Dari hasil penelitian ini dapat disimpulkan bahwa terdapat hubungan bermakna antara kebiasaan merokok dengan terjadinya disfungsi ereksi pada sopir angkutan umum di Terminal Karombasan Manado.

\section{SARAN}

Disarankan kepada sopir angkutan umum untuk mengurangi atau bahkan dapat menghentikan kebiasaan merokok. Bila telah terdapat gejala dan tanda disfungsi ereksi, sopir sebaiknya melakukan pemeriksaan dan pengobatan ke dokter ahli.

\section{DAFTAR PUSTAKA}

1. Wibowo AF, Yuliadi I, Karyanta NA. Perbedaan derajat disfungsi ereksi pria dewasa awal ditinjau dari tingkat stres di Kelurahan Jagalan Surakarta. Jurnal Candrajiwa. 2013:83-92.

2. Bivalacqua TJ, Usta MF, Champion HC, Kadowitz PJ, Hellstrom WJG. Endothelial dysfunction in erectile dysfunction: role of the endothelium in erectile physiology and disease. $\mathbf{J}$ Androl. 2003;24(S6).

3. Refarat Kedokteran: Disfungsi ereksi, etiologi, dan klasifikasi. [cited 2014 Nov 15]. Available from: http://www. 
Rusdi, Turalaki, Satiawati: Hubungan antara merokok...

infokedokteran.com/refarat-

kedokteran/refarat-kedokteran-

disfungsi-ereksi-etiologi-dan-

klasifikasi.html

4. Keputusan menteri perindustrian dan perdagangan RI. Pedoman cara uji kandungan kadar nikotin dan tar rokok. No 62/ MPP/ Kep/2. 2004

5. Syazilimustofa. Bahaya rokok. 2011 Februari 1. Available from: http://blog. unila.ac.id/ syazilimustofa.

6. Rosita R, Suswardany DL, Abidin Z.
Penentu keberhasilan berhenti merokok pada mahasiswa. Kemas. 2012;8(11):19.

7. Gondodiputro S. Bahaya tembakau dan bentuk-bentuk sediaan tembakau. Bandung: Bagian Ilmu Kesehatan Masyarakat Fakultas kedokteran Universitas Padjadjaran; 2007.

8. Anggarda. Rokok, kolestrol dan impotensi. 2009 Nov 30. Availablef from: http://anggarda.wordpress. com/2009/ 11/30/rokok-kolestrol-danimpotensi. 